\title{
CAUGHT BETWEEN THREE FIRES Book Review (Leiden: INIS, 2003; 334 halaman)
}

\author{
Ridwan Rosdiawan
}

\begin{abstract}
Abstrak
Judul besar Caught betweem Three Fires memberikan sinyal akan adanya tiga variabel yang 'memantik api' penelitian ini. Variabel pertama adalah fungsi dan peran penghulu yang telah mapan dalam struktur social masyarakat Jawa dan Madura. Variabel kedua berupa upaya pemerintah colonial Belanda untuk mengintegrasikan institusi informal penghulu ke dalam system mereka. Variabel ketiga adalah tumbuh dan berkembangnya reformisme Islam yang bersumber dari Timur Tengah dan munculnya gerakan nasionalis.

Dasar dari praktik-praktik ke-Pangulu-an adalah sebuah "misi suci" memperjuangkan

kelestarian Syari'at Islam dalam kehidupan masyarakat. Dan dalam misi suci itu para Pangulu berhasil menunaikannya sekalipun mereka mendapatkan tekanan-tekanan hebat dari pihak penguasa yang secular dan non-Muslim.
\end{abstract}

Kata Kunci: skill, sejarah, metodologi

\section{A. Review Penyusun dan Karyanya}

Buku dari disertasi yang penyusunannya selesai pada tahun 2001 ini adalah karya Muhammad Hisyam dalam upayanya meraih gelar Doktor di Universiteit Leiden The Netherlands. Sang penulis menyelesaikan studi S1-nya di Jurusan Sejarah Kebudayaan Islam IAIN Yogyakarta dan meraih gelar Master dalam bidang sosiologi di Universitas Indonesia dengan spesialisasi agama dan kemasyarakatan. Proses penyusunan disertasi ini menghabiskan waktu 9 tahun. Penelitian dimulai ketika penulis mengawali studinya di Leiden tahun 1992. Saat itu ia telah berprofesi sebagai peneliti di CSCS LIPI dan menduduki jabatan kepala bagian agama dan filsafat.

Bagi mereka yang berkesempatan mengambil studi di Belanda, pemilihan topic penelitian dengan focus studi sejarah Indonesia pada masa colonial adalah sebuah 
keputusan yang tepat. Negara ini memiliki beberapa perpustakaan nasional dengan koleksi artefak colonial terlengkap. Rekaman sejarah di bidang politik, ekonomi maupun social-kemasyarakatan dari setiap rentangan masa pendudukan Belanda di Indonesia tersimpan dengan rapi dalam bentuk manuscript, memoir, microfilm atau buku. Kesemua bentuk arsip tersebut dapat dengan mudah diakses public di perpustakaanperpustakaan seperti Algemeen Rijksarchieft (ARA), Van Vollenhaven Institute, Oosterse Letteren en Geschiedenis (OLG) Universiteit Leiden atau di Koninklijk Instituut voor de Taal, -Land, en -Volkenkunde (KITLV). Dengan 'pemanjaan' literature seperti di atas maka tak heran bila hasil-hasil karya studi historiografi Indonesia yang dilakukan di Belanda selalu menawarkan fakta-fakta baru yang ditunggu.

Di samping itu, latar belakang skill sang penulis dalam penguasaan bahasa-bahasa pendukung juga menjadi nilai tambah dari disertasi ini. Mayoritas referensi utama yang menjadi dasar acuan karya ini adalah manuscript-manuscript yang ditulis dalam bahasa Belanda. Meski diakui penulis bahwa kemampuannya dalam bahasa Belanda sangat terbatas, kondisi tersebut bukan merupakan sebuah halangan besar. Mencari penterjemah 'sukarela' bahasa Belanda di Leiden tidak begitu sulit. Kredibilitas penulis tampak dalam penguasaannya terhadap bahasa dan tulisan Jawa serta Arab-Melayu. Dia dengan tangkas membedah referensireferensi manuscript local yang pada akhirnya membantunya dalam memeparkan fakta dan mempertajam analisis. Selain itu, factor pembimbing juga berkontribusi. Supervisi dan arahan Prof. Dr. Christian "Kees" van Dyke -Seorang Professor dalam studi Indonesia-menawarkan nuansa 'menjanjikan' bagi siapapun yang membaca karya ini.

\section{B. Resume Latar Belakang Pemilihan Topik Penelitian}

Dari judulnya, Disertasi "Caught Between Three Fires: The Javanese Pangulu Under The Dutch Colonial Administration

1882-1942" memberikan impresi yang jelas mengenai point-point inti yang menjadi sentral pembahasannya. Studi ini menyoroti tugas, fungsi, wewenang serta peran yang dimainkan penghulu dalam suatu fase di rentangan masa colonial Belanda.

Fakta sejarah menunjukkan bahwa sejak masa awal pembentukan 
kerajaan Islam di Jawa penghulu telah memainkan peranan penting dalam men-sinkron-kan 'kehendak langit' dengan realitas kehidupan social. Sebagai individu mereka adalah pemuka-pemuka agama di lingkungannya yang pendapatnya berimplikasi religio-legal yang otoritatif. Pengaruh tersebut dalam banyak kasus mengangkat strata peran mereka sebagai sebuah lembaga advisory informal yang keberadaannya diakui oleh raja/pemerintahan.

Fungsi dan peran penghulu ini kemudian berada dalam 'masalah' ketika ada intervensi --baik langsung ataupun tidak-- yang mengusiknya. Periodisasi 1882-1942 yang dipilih penulis dalam membatasi studi ini mengisyaratkan keunikan fase yang menandai interaksi peran status quo penghulu dengan variabel-variabel lain yang mengintervensinya. Ada dua variabel utama yang disinyalir berpengaruh besar dalam merekonstruksi posisi dan peran penghulu. Yang pertama adalah diafiliasikannya penghulu ke dalam struktur lembaga resmi di bawah system pemerintahan colonial Belanda, dan yang kedua adalah menjamurnya pergerakan-pergerakan Islam dan nasionalis di Indonesia sebagai akibat dari intensitas kontak antara nusantara dengan dunia luar. Berdasarkan deskripsi fenomena situasi tersebut, kajian mengenai dialektika antara variabel-variabel di atas menjadi sangat signifikan.

Studi seputar sejarah eksistensi penghulu di Indonesia memang telah banyak dilakukan. Setidaknya ada dua karya klasik yang telah ditempuh oleh ilmuwan Belanda dengan focus status penghulu dalam struktur pemerintahan VOC. H. P. Grobbee dalam disertasinya De Panghoeloe als Advisor in Strafzaken (1884) mengkaji fungsi penghulu sebagai penasihat bagi lembaga peradilan local (landraad) khususnya dalam kasus hokum criminal yang terjasi antara warga pribumi. Disertasi Van de Velde yang berjudul De Godsdienstige Rechtspraak in Nederlandsch-Indie (1928) mengambil focus penerapan kaidah-kaidah umum hokum positif dalam peradilan agama di Indonesia. Selain kedua karya klasik tersebut, studi modern yang dilakukan Daniel S. Lev (1972) dan M.B. Hooker (1984) juga menyoroti interkoneksitas antara peran peradilan agama dengan interest politik dari kebijakan pemerintahan colonial. Studi Husni Rahim (1998) tentang system otoritas dan administrasi yang diterapkan oleh pejabat agama pada masa kesultanan 


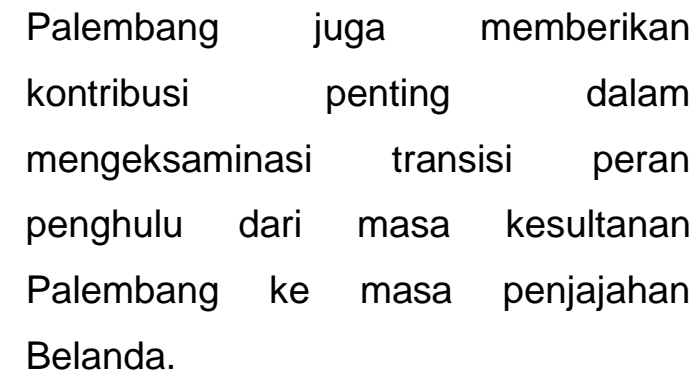

Meski kaya dengan ilustrasi penjabaran fungsi dan peran penghulu dalam struktur masyarakat Indonesia, karya klasik dan modern tersebut di atas tampak seragam dalam meletakkan posisi penghulu yang tak lebih dari sekedar obyek intervensi politik. Studi-studi tersebut tidak begitu memperhatikan kajian mengenai kemungkinan peran yang dimainkan oleh individu-individu pejabat penghulu dalam kapasitasnya sebagai pemuka agama. Padahal dualisme peran yang dijalankan oleh individu-individu tersebut justru menempatkan mereka dalam posisi yang dilematis. Di satu sisi sebagai pejabat pemerintah mereka harus tunduk pada kebijakan politik, sementara di sisi lain sebagai pemuka agama mereka ditunut untuk mempertahankan nilai-nilai fundamental agama yang dianut masyarakat di lingkungannya. Di tengah gap studi yang ditinggalkan oleh karya-karya klasik dan modern inilah Muhammad Hisyam memfokuskan pembahasannya.

\section{Review Metodologis}

Sebagaimana tampak dalam latar belakang di atas, judul besar Caught betweem Three Fires memberikan sinyal akan adanya tiga variabel yang 'memantik api' penelitian ini. Variabel pertama adalah fungsi dan peran penghulu yang telah mapan dalam struktur social masyarakat Jawa dan Madura. Variabel kedua berupa upaya pemerintah colonial Belanda untuk mengintegrasikan institusi informal penghulu ke dalam system mereka. Variabel ketiga adalah tumbuh dan berkembangnya reformisme Islam yang bersumber dari Timur Tengah dan munculnya gerakan nasionalis. Pertanyaan inti penelitian yang muncul berikutnya adalah: "Bagaimanakah status fungsi dan peran penghulu selanjutnya ketika ketiga variabel di atas berinteraksi?".

Demi kemudahan pembahasan, pertanyaan inti tersebut kemudian dipecah menjadi dua permasalahan penelitian, yaitu: "Peran penting apakah yang diemban penghulu dalam konteks kehidupan social?", dan "Bagaimanakah mereka mengejawantahkan peran penting tersebut?". Permasalahan penelitian tersebut berkonsekuensi pada diperlukannya sebuah pendekatan yang memandang penghulu tidak 
hanya sebagai agen pemerintah yang ditempatkan di peradilan agama tetapi juga sebagai pemuka agama yang mempunyai pengaruh di kalangan masyarakat muslim. Kemudian dari permasalahan itu lahirlah tujuan penelitian yang berupa pemetaan posisi penghulu di tengah himpitan tuntutan modernisasi dari pemerintahan colonial dan kewajiban untuk mempertahankan nilai-nilai tradisional agama. Tujuan berikutnya adalah mengkaji peran dan efektifitas kepemimpinan penghulu di tengah euphoria era reformasi agama dan maraknya pergerakan nasional.

Pemilihan periodisasi waktu 1882-1942 jelas mempunyai konteks yang spesifik, dimana yang pertama merupakan tonggak diresmikannya penghulu sebagai bagian dari legalformal pemerintahan colonial dan batasan waktu terakhir adalah masa berakhirnya pendudukan colonial Belanda di Indonesia. Meskipun demikian, bukan berarti masa pra1882 dan pasca-1942 luput dari sorotan. Review umum terhadap dinamika pra- dan pasca periodisasi disajikan secara sistematis yang memperjelas peta kajian pada fase waktu yang menjadi focus.

Kerangka pembahasan yang dilakukan penulis terskema dengan rapi. Dalam penjabarannya mengenai status fungsi dan peran penghulu sebelum tahun 1882 penulis menggali informasi dari beragam manuscript yang tersimpan di perpustakaan kesultanan Yogyakarta dan Surakarta. Beberapa arsip yang diakses dari perpustakaan Kerajaan Belanda (ARA) di Amsterdam juga melengkapi referensi yang memberikan ilustrasi utuh. Sementara untuk mengkaji posisi, struktur organisasi, tugas serta tanggungjawab penghulu di bawah system colonial, penulis menggunakan arsip-arsip kolonial berupa surat-surat resmi pengangkatan dan pemberhentian penghulu, biografi dari masing-masing penghulu yang dipromosikan, keputusan-keputusan yang dikeluarkan peradilan agama, serta surat-surat nasehat dan permohonan nasehat yang ditulis oleh atau melibatkan penghulu itu sendiri. Sedangkan untuk memetakan peran social penghulu dan pola hubungan mereka dengan gerakan reformasi agama dan pergerakan nasional, penulis mengakses informasi dari koran-koran klasik yang diaksesnya di Arsip Nasional Jakarta, perpustakaan Van Vollenhaven Instituut dan KITLV di Leiden.

Untuk memperkaya pengkajian penelitiannya dan untuk menutupi 
lobang gap yang ditinggalkan studi pustaka, penulis juga mempraktikan beberapa instrument pengumpul data. Dia melakukan observasi di beberapa kota di Jawa Baratdan Jawa Tengah untuk mendapatkan gambaran empiris mengenai lokasi-lokasi yang pernah dijadikan pusat kegiatan penghulu pada masanya. Beberapa proses wawancara juga dilakukan penulis dengan keturunan-keturunan dua penjabat penghulu yaitu Mas Hadji Ichsan dan Raden Hadji Mohammad adnan. Wawancara juga dilakukan dengan Pangulu Ageng kraton Yogyakarta berikut staf-stafnya dengan tujuan untuk memahami struktur organisasi pejabat agama di lingkungan kraton.

Data-data yang diperoleh selanjutnya dianalisis oleh penulis dengan menggunakan pendekatan historis-sosiologis. Pendekatan ini ditempuh dalam upaya memahami hubungan antara aktifitas atau pengalaman personal dengan struktur social di lingkungannya sebagai sebuah bangunan proses yang berkelanjutan. Analisa data sejarah dengan menggunakan pendekatan ini menawarkan sebuah kerangka konseptual unik yang tidak hanya menggambarkan fenomena masa lalu tetapi juga menyajikan representasi dari bagaimana peristiwa tersebut terekonstruksi.

\section{Resume Hasil Penelitian}

Istilah "Caught between Three Fires" adalah terjemahan Bahasa inggris dari idiom Bahasa Belanda "Tussen Drie Vuren". Kalimat ini dimunculkan oleh Clifford Geertz dalam bukunya Islam Observed dengan merujuk pada istilah yang beredar luas di kalangan Pangulu pada akhir abad 19 dan awal abad 20. Istilah tersebut adalah analogi yang digunakan oleh para pangulu untuk mendiskripsikan kesadaran diri (selfconsciousness) terhadap posisi peran yang mereka pegang. Para pangulu memandang bahwa mereka adalah agen dari kehendak Tuhan dan bertugas menerjemahkan 'kehendak agung' itu di tengah kehidupan social, sementara realitas lingkungan saat itu memaksa mereka untuk bernegosiasi dengan 'keinginan' pemerintah colonial yang berkuasa dan dinamika 'keinginan' masyarakat bawah yang menuntut perubahan.

Eksistensi pangulu sebagai 'pemuka' atau pemegang otoritas keagamaan dalam kehidupan masyarakat Jawa telah terbentuk jauh sebelum masa colonial dan telah mapan bahkan sejak masa-masa awal 
kerajaan Islam. Kemapanan posisi pangulu dalam struktur pemerintahan kerajaan didukung oleh fakta bahwa sejak masa awal konsepsi kerajaan Islam factor kehidupan beragama tidak bisa dipisahkan dari kehidupan secular. Contoh nyata dari integritas Negara dan Agama ini tampak jelas dalam gelar kesultanan Yogya yang menyebut beberapa istilah seperti Sampeyan Dalem Hingkang Sinuwun yang merupakan symbol kekuasaan pemerintahan, Senopati Hing Ngalaga yang melambangkan kekuasaan tertinggi militer dan Sayidin Panatagama Kalipatullah yang menunjukkan kekuasaan tertinggi dalam kehidupan beragama. Penjabaran hierarki dari kekuasaan yang dimiliki oleh Sultan dalam ketiga bidang ini juga diperjelas dengan pengangkatan beberapa deputi seperti Patih yang membantu sultan dalam bidang pemerintahan, Hadipatih sebagai asisten bidang militer dan Pangulu sebagai pendamping utama Sultan dalam bidang keagamaan. Relasi kebersatuan tiga elemen ini juga tampak dalam penyusunan tata ruang ibukota pemerintahan yang senantiasa mengintegrasikan tiga unsur Kraton-Alun-alun-Mesjid.

Karena factor kehidupan beragama merupakan salah satu unsur utama dalam kehidupan bernegara, maka pengurusannya pun ditempuh dalam cara-cara yang formal melalui pembentukan beberapa badan yang disusun secara hierarkis dari lingkungan pemerintahan pusat hingga bisa bersentuhan langsung dengan masyarakat. Dalam struktur pemerintahan pusat kerajaan Mataram, sebuah departemen yang khusus menangani permasalahan Agama Islam dibentuk dan dikepalai oleh seorang Pangulu Ageng. Kesultanan Surakarta menamai departemen ini dengan Yogaswara, sementara Kesultanan Yogya menamainya dengan Suranata. Depertemen ini beranggotakan 40 orang yang menggambarkan syarat minimum dari diberlangsungkannya Shalat Jum'at menurut Mazhab syafi'i.

Dalam struktur masyarakat, Pangulu Ageng digolongkan sebagai kelas priyayi sehingga dalam beberapa acara resmi kerajaan dia harus mengenakan seragam kebesaran laksana Sultan. Fungsi utama yang dijalankan oleh pangulu Ageng ini adalah mengatur keseluruhan kegiatan keagaamaan yang berkaitan langsung dengan kraton, dan fungsi ini dikejawantahkan melalui dua koridor yaitu sebagai kepala Masjid Agung dan Ketua Pangadilan Surambi. 
Sebagai kepala Masjid Agung, Pangulu Ageng bertanggung jawab menjadi corong Kraton dalam penegakan hukum Islam dan dalam pelaksanaan ritual agama khususnya di lingkungan istana. Dalam melaksanakan tugasnya, pangulu Ageng dibantu oleh Sembilan Ketib (Khatib), Lima Mudin (Mu'adzin), dan empat puluh Ngulomo ('Ulama), dan beberap[a Merbot. Pangulu Ageng adalah imam utama mesjid baik dalam shalat 5 waktu ataupun dalam Shalat Jum'at. Sementara Mudin bertindak sebagai pembaca Adzan panggilan shalat, Ketib bertindak sebagai Khatib pada Shalat Jum'at. Ngulomo mempunyai tugas utama yang berkaitan dengan pengurusan jenazah dan upacara penguburan serta menjaga dan mengurus makammakam keramat di lingkungan kraton. Ngulomo juga berfungsi sebagai pengkhutbah jika seandainya sang Ketib berhalangan hadir. Sedangkan Merbot adalah struktur terendah dari kepengurusan mesjid. la bertanggung jawab atas kebersihan dan pemeliharaan inventaris mesjid. Dalam seluruh kegiatan Mesjid Kraton ini, Pangulu Ageng bertindak sebagai pemimpin utama dan penanggung jawab sehingga jika ada upacaraupacara Kraton yang berhubungan dengan Mesjid seperti pernikahan keluarga kerajaan Pangulu Ageng selalu bertindak sebagai pemimpin prosesi.

Sementara dalam kapasitasnya sebagai pemimpin Pangadilan Surambi, Pangulu Ageng mengemban tugas menjalankan fungsi yudikatif dalam menangani kasus-kasus hukum yang melibatkan masyarakat. Awalnya, Pengadilan Surambi menangani kasus hukum yang luas yang meliputi permasalahan hukum keluarga, ekonomi bahkan criminal. Namun, setelah tahun 1831 kekuaasaan Pangulu dibatasi hanya pada beberapa bagian hukum keluarga dan ekonomi yang meliputi pernikahan, perceraian, rekonsiliasi keluarga (ruju'), Nafkah, pembagian harta gonogini, pembagian warisan, wakaf, dan perselisihan harta perusahaan kerjasama (syirkah/mudarabah). Walaupun kekuasaannya telah dipangkas, pangulu di sepanjang abad 19 selalu dilibatkan sebagai dewan pertimbangan dalam masalah hukum criminal berat yang berimplikasi hukuman mati.

Poses yudikatif yang dipimpin oleh Pangulu ini berlangsung di beranda mesjid dan oleh karena itulah proses ini dinamakan Pangadilan Surambi. Dalam administrasinya, 
Pangulu Ageng dibantu oleh beberapa asisten yang terdiri dari delapan Ketib (Katib/juru tulis), enam Mudin, dua atau tiga Ngulomo, satu Jakso, dan satu Kori sebagai pembawa acara. Adapun landasan hukum yang dipakai sebagai kitab pedoman penyelenggaraan pengadilan tersebut semuanya berlandaskan pada kitabkitab Fiqh mazhab syafi'i dan pemerintahan kerajaan samasekali tidak mempunyai kitab baku indigenous yang menjadi pegangan. Kitab Hukum Pekih yang menjadi acuan proses pengadilan sangatlah banyak dan beragam, tetapi ada empat kitab induk yang selalu menjadi rujukan utama yaitu kitab Mukarrar (Muharrar), Kitab Makalli (Mahalli), Tupah (Tuhfah al-Muhtaj) dan Kitab Patakulwahab (Fath al-Wahhab).

Sistem ke-Pangulu-an yang berlaku di lingkungan Kraton atau pusat pemerintahan kerajaan juga berlaku di tingkatan pemerintahan di bawahnya. Di tingkat kabupaten, pangulu menjadi corong agama bagi Bupati dan di tingkat kecamatan terdapat Na'ib yang menjadi asisten Camat dalam bidang keagamaan, sementara di desa terdapat 'Amil atau dalam istilah lain Kaum dan Lebe sebagai asisten Lurah. Pangulu kabupaten adalah kepala bidang keagamaan Islam dan bertanggung jawab atas urusan yang menyangkut pendidikan agama, pernikahan dan mengadili kasus-kasus keluarga seperti perceraian, pembagian warisan, wakaf dan lain-lain. Dalam bidang pengadilan kasus-kasus umum seperti criminal, pangulu kabupaten menduduki posisi penasehat bupati bersama dengan jaksa. Pelaksanaan tugas rutin Pangulu kabupaten di bantu oleh beberapa Ketib yang masing-masing dinamai sesuai dengan keahlian dan masalah yang ditanganinya. Ketib Pekih adalah staf ahli yang membantu Pangulu dalam penelusuran hukum-hukum yang terdapat dalam Fiqh. Ketib Prabot membantu Pangulu kabupaten dalam pengadministrasian dan inventarisasi property yang menjamin keberlangsungan kegiatan rutin Pangulu. Sedangkan Ketib Kojah (hujjah) membantu Pangulu dalam menjelaskan dan menerangkan seputar tanya-jawab mengenai permasalahan agama Islam. Di tingkat kecamatan, Naib kadang juga disebut Kalipah menjalankan fungsi Pangulu hanya sebatas dalam kasus pernikahan dan perceraian. Naib tidak diberi otoritas untuk menjalankan fungsi kehakiman agama sehingga dia tidak bisa menangani kasus-kasus 
seperti pembagian warisan atau gugatan cerai yang diajukan kaum perempuan. Sementara di tingkat desa, Kaum, 'Amil, atau Lebe hanya berfungsi sebagai penghubung. Mereka bertugas mendampingi calon mempelai pengantin atau membantu yang hendak berperkara dalam urusan keluarga dan masalah warisan ke Naib di kecamatan.

Penghasilan para Pangulu umumnya tidak begitu besar. Mereka memang mendapatkan upah dari Kerajaan berupa tanah dan property. Mereka juga mendapatkan bagian dari biaya penanganan kasus-kasus yang diurusnya. Tetapi andalan utama kehidupan mereka biasanya kasil wiraswasta dari berdagang atau bertani. Tampaknya, yang menjadi daya tarik utama dari posisi Pangulu ini adalah implikasi wibawa dan pengaruh yang ditimbulkannya di tengah masyarakat. Para Pangulu ini berlatarbelakang pendidikan agama Islam yang cukup kuat. Mulai dari menempuh pendidikan dasar di Langgar atau di Mesjid dengan mempelajari tatacara shalat, hafalanhafalan surat-surat pendek dan membaca al-Qur'an, para calon pangulu kemudian meneruskan pendidikannya ke pesantren-pesantren dan madrasah untuk memperluas dan memperdalam pengetahuan mereka dalam bidang agama Islam. Tentu saja, proses menjadi Pangulu bukanlah sebuah proses yang mudah dan harus menempuh kompetisi yang panjang dan ketat. Persyaratan umum utama untuk menjadi Pangulu adalah Ahli dalam bidang hukum Islam, mempunyai kemampuan administrative dan setia pada penguasa. Namun, factor penentu seseorang masuk dalam jajaran kandidat Pangulu adalah tingkat kedekatan mereka dengan penguasa. Maka tak heran jika biasanya jabatan Pangulu ini turun dari ayah ke anak. Sebelum menduduki posisi utama, para calon Pangulu biasanya menempuh proses Magang, yaitu menjadi pembantu di tempat kerja Pangulu. Proses magang ini bisanya berlangsung lebih dari sepuluh tahun dan biasanya keturunan ningrat dari kasta yang tertinggi lah yang mempunyai kesempatan lebih besar untuk menjadi Pangulu utama.

Pada awal abad 19, ketika VOC semakin memantapkan posisinya di daerah Jawa dan Madura sehingga memungkinkan mereka untuk membentuk pemerintahan Hindia Belanda, posisi Pangulu khususnya di kabupaten-kabupaten yang jauh dari wilayah kraton mengalami masa-masa 
turbulensi. Pangulu di wilayah Kraton praktis belum menghadapi permasalahan yang berarti karena pemerintah Hindia Belanda memberikan hak otonomi kepada Sultan untuk mengatur sendiri wilayahnya meski teritorialnya terbatas. Sementara Pangulu-pangulu di luar kraton harus berhadapan dengan upaya Belanda yang berusaha menerapkan hukum Eropa di kabupaten-kabupaten yang menjadi jajahannya termasuk dalam wilayah urusan yang sebelumnya telah lama menjadi domain penghulu. Namun karena terdapat perbedaan yang substansial antara hukum Eropa yang berlandaskan ideology secular dan domain penghulu yang berbasis hukum agama Islam upaya pemerintahan Hindia Belanda selalu menghantam benteng terjal sehingga kegiatan Pangulu tetap berada di luar jangkauan administrasi mereka. Walaupun demikian, para Pangulu senantiasa dilibatkan sebagai advisor setiapkali pemerintah Hindia Belanda melakukan kodifikasi hukum-hukum sosial yang akan diberlakukan di wilayah kekuasaannya. Upaya-upaya bernuansa 'mediasi' yang ditempuh oleh pemerintah Belanda ini tentu saja dimaksudkan untuk meminimalisir tingkat resistensi yang mungkin saja timbul akibat ketidakpuasan masyarakat local terhadap kekuasaan mereka.

Baru sekitar 60 tahun kemudian, atau tepatnya tahun 1882, pemerintah Hindia Belanda akhirnya memasukkan kegiatan ke-Pangulu-an ke dalam administrasi mereka. Pada tahun tersebut dibentuk Priesterraad atau Raad Agama (Pengadilan Agama) yang memformalkan aktifitas Pangulu di Jawa dan Madura sebagai bagian dari administrasi Pemerintah Belanda yang bersandingan dengan Landraad (Pengadilan Umum). Korporasi ini pada perkembangan selanjutnya jelas memicu revolusi dalam keorganisasian dan fungsi dari Pangulu. Secara hierarkis, Raad Agama adalah subordinat dari Landraad sehingga keputusan Pangulu di Raad Agama baru berkekuatan hukum bila telah mendapat persetujuan dari Landraad. Selain itu, keputusan tertinggi yang tadinya hanya bertumpu di seorang Pangulu utama kini harus melalui keputusan bersama (Collegial) di mana Pangulu dan asistennya yang terdiri dari 3 - 8 ulama harus secara bersama-sama menandatangani putusan tersebut. Sistem seperti ini terus berlangsung bahkan hingga pemerintahan colonial Belanda berakhir. 
Efek yang paling nyata dari dimasukkannya pengulu ke dalam Priesterraad adalah dua konsekuensi yang berimplikasi panjang. Konsekuensi pertama adalah bahwa pangulu yang tadinya ditunjuk dan diangkat oleh penguasa local kini ditentukan oleh pemerintah colonial Belanda dan dengan demikian control terhadap segala aktifitas Pangulu pun diatur penuh oleh Belanda. Kedua, tata laksana aktifitas dari pangulu dalam Pristerraad harus sejalan dengan administrasi modern yang dijalankan oleh pemerintah Hindia Belanda. Implikasi dari dua konsekuensi ini kemudian tampak dalam hal remunerasi. Pangulu tidak lagi menerima upah dari penguasa local, sementara pemerintah Hindia Belanda tidak memberikan upah khusus bagi Pangulu dan asistennya. Kantor Priesterraad dituntut untuk membiayai operasional dan upah karyawan secara mandiri dengan mengandalkan penghasilan dari biaya penanganan kasus dalam yurisdiksi yang mereka jalankan sehari-hari. Pangulu memang mendapatkan upah dari pemerintah Hindia Belanda tapi bukan dalam posisi mereka sebagai kepala Priesterraad, melainkan dari posisinya sebagai advisor bagi Landraad.
Implikasi lain yang kemudian timbul adalah perubahan signifikan dalam proses rekrutmen calon Pangulu. Ketika Priesterraad dibentuk, Pemerintah Belanda menganggap bahwa kebanyakan Pangulu pada saat itu kurang memenuhi syarat dan tidak mempunyai kemampuan yang cukup untuk menjalankan administrasi modern. Tahun 1889 akhirnya sebuah badan yang mengurusi permasalahan pribumi dibentuk dan berperan besar dalam perekrutan Pangulu. Proses perekrutan ini diawali oleh pengajuan beberapa nama calon Pangulu oleh Bupati kepada Residen. Residen kemudian menyampaikan proposal ini ke Direktorat Kehakiman yang selanjutnya meminta pertimbangan terhadap kantor urusan pribumi yang melakukan penyeleksian berkasberkas pengajuan. Di Kantor inilah nama-nama yang ditetapkan kemudian menjabat sebagai Pangulu kepala Priesterraad di tiap kabupaten. Lima tahun berikutnya proses perekrutan Pangulu mengalami impropisasi lanjutan. Setelah tahun 1894, setiap kandidat Pangulu diwajibkan melampirkan Verklaring (pernyataan) yang terdiri dari berkas-berkas berupa Curriculum Vitae yang mencantumkan data-data latar belakang pendidikan, pengalaman kerja dan posisi yang 
pernah diduduki, posisi yang pernah diduduki oleh leluhur, serta tingkat kedekatan koneksi dengan pejabat tinggi. Para kandidat Pangulu juga diwajibkan menguasai bahasa resmi yaitu bahasa Melayu dan bahkan Bahasa Belanda serta mampu menulis dalam huruf latin. Skill lain yang harus dimiliki juga tergambar dari persyaratan yang mewajibkan para kandidat Pangulu untuk menulis Verklaring mereka dalam tiga bentuk tulisan; Tulisan Jawa, arab dan latin. Pada perkembangan selanjutnya, proses kualifikasi Pangulu terus dimodernkan. Pada awal abad dua puluh, system ujian bagi proses rekrutmen Pangulu mulai ditempuh. Penguji adalah sebuah tim yang terdiri dari empat ulama besar yang berpengaruh, dimana tiga di antaranya adalah Syaikh besar dari Arab. Adapun skill yang diujikan biasanya meliputi kemampuan membaca dan memahami kitab fath al-Mu'in, menulis dalam huruf Jawa, Arab dan Latin, pengetahuan seputar Raad Agama serta administrasinya, dasar-dasar Hukum Islam serta kecakapan dalam Bahasa Arab. Tuntutan kualitas yang dibebankan kepada Pangulu ini mendorong mereka untuk berbenah diri di tengah enggannya pemerintah Hindia Belanda untuk menggagas sekolah khusus ke-Pangulu-an. Akhirnya atas inisiatif dan semangat mereka, para Pangulu berhasil menggagas pendirian sebuah lembaga pendidikan yang mereka namai Manbaul 'Ulum.

Implikasi yang timbul dari posisi pangulu sebagai agen pemerintahan Hindia Belanda juga mempunyai keunikan. Mereka seringkali melakukan aktifitas yang kontradiktif tetapi justru memainkan peran mediasi. Di satu sisi pangulu dituntut menjadi corong sosialisasi pencitraan Belanda sehingga masyarakat merasa tidak keberatan berada di bawah administrasi asing. Di sisi lain, para Pangulu juga berperan aktif dalam menyampaikan aspirasi-aspirasi keberatan masyarakat terhadap kebijakan-kebijakan pemerintah Hindia Belanda. Para Pangulu bahkan menjadi garda terdepan pertahanan masyarakat Islam dalam menangkal dan mengcounter aktifitas-aktifitas missionaries yang membawa misi kristenisasi.

Pada masa yang sama di awal abad dua puluh, perkembangan trend baru dalam proses sosio-politik di Indonesia juga tengah berlangsung sebagai akibat dari semakin intensnya akses masyarakat Muslim Indonesia dengan dunia Islam lainnya. Trend ini 
ditandai dengan maraknya gerakan pembaharuan Islam yang masingmasing mengusung platform nasionalisme dan menyulut sisi radikalisme masyarakat di wilayah Jawa dan Madura. Kondisi ini memaksa pemerintah Hindia Belanda untuk selalu terus waspada terhadap kemungkinan munculnya pemberontakan missal terhadap kekuasaan mereka.

Fenomena ini juga sangat berpengaruh secara signifikan terhadap pola peran dan fungsi yang telah lama sebelumnya dipegang dan dijalankan Pangulu. Posisi sebagai corong sosialisasi pemerintah colonial yang memfasilitasi mereka dalam menjalankan fungsi mediasi justru menjadi boomerang. Kebencian kelompok reformis Islam terhadap pemerintahan colonial yang nonMuslim serta keterbatasan dalam melakukan perlawanan mendorong mereka untuk "menyerang" institusi Pangulu. Serangan ini dilakukan melalui cara-cara pendiskreditan dengan mendemonisasi Pangulu sebagai kaki tangan pemerintah kafir. Kritik tajam terhadap aktifitas Pangulu mulai bermunculan ketika para reformis Islam mempublikasikan bulletin Islam Bergerak yang mempertanyakan kredibilitas dan kompetensi mereka sebagai ulama dan hakim agama. Para reformis mencela praktik Pangulu dalam pengutipan uang perkara dari masyarakat sebagai aktifitas korupsi yang bertujuan untuk memperkaya diri serta menuduh para Pangulu telah memanipulasi ajaran Islam demi kepentingan kekuasaan pemerintah colonial dan nafsu diri. Tuduhantuduhan ini kemudian menjadi polemic panjang di tengah masyarakat dan kredibilitas Pangulu benar-benar dalam posisi terancam. Rebutan pengaruh antara Pangulu dengan kaum reformis dalam menarik simpati masyarakat terus terjadi dan satusatunya kekuatan yang membantu posisi Pangulu adalah kekuatan administrative mereka sementara kaum reformis terus menancapkan eksistensi seiring dengan bergabungnya ulama-ulama berpengaruh dalam organisasiorganisasi yang mereka bentuk.

Sadar akan menurunnya pamor mereka sebagai akibat dari 'seranganserangan' kritik ulama reformis para pangulu kemudian menempuh beberapa cara mediasi dan rehabilitasi. Untuk memulihkan nama baik mereka, para Pangulu kemudian menjalin kerjasama yang intens dengan ormas-ormas Islam serta 
mendengar advis-advis dari ulama berpengaruh dalam rangka memperbaiki kinerja mereka khususnya dalam pengelolaan dan peningkatan pelayanan Priesterraad. Dan sebagai upaya konsolidasi internal mereka untuk memperkuat diri dari 'serangan-serangan' luar, para pangulu kemudian membentuk sebuah organisasi profesi dalam rangka menggalang solidaritas di antara mereka. Perserikatan Penghulu dan Pegawai Mesjid (PPPM) yang didirikan sekitar tahun 1920-an dan kemudian Perhimpunan Penghulu dan Pegawainya (PPDP) yang berdiri pada tahun 1937 adalah hasil dari upaya para Pangulu dalam mengcounter perkembangan-perrkembangan baru yang 'menyerang' fungsi dan peran mereka.

\section{E. Kesimpulan Studi}

Kesimpulan dari studi ini adalah bahwa dasar dari praktik-praktik kePangulu-an adalah sebuah "misi suci" memperjuangkan kelestarian Syari'at Islam dalam kehidupan masyarakat. Dan dalam misi suci itu para Pangulu berhasil menunaikannya sekalipun mereka mendapatkan tekanantekanan hebat dari pihak penguasa yang secular dan non-Muslim. Mereka juga berhasil mempertahankan eksistensi dari 'serangan-serangan' hebat yang dilancarkan oleh sesame organisasi Muslim yang pada saat bersamaan tumbuh bak jamur di musim hujan. Tingkat survivalitas dari eksistensi Pangulu ini sangat ditentukan oleh pendekatanpendekatan yang mereka lakukan dalam mengkompromikan "misi suci" mereka dengan dinamika kenyataan yang terus berkembang dalam kehidupan sosio-politis di sekitar mereka. 